\title{
ATYPICAL PERIANAL HERPES SIMPLEX INFECTION IN HIV-POSITIVE PATIENTS
}

Marcelo Simonsen, Sergio Carlos Nahas, Edesio Vieira da Silva Filho, Sergio Eduardo Alonso Araújo, Desiderio Roberto Kiss, Caio Sergio Rizkallah Nahas

\section{INTRODUCTION}

Anal lesions affect up to $34 \%$ of patients with Acquired Immunodeficiency Syndrome (AIDS), ${ }^{1}$ and are more frequent in males who have sex with males (MSM). ${ }^{2}$ The most common anal infection in human immunodeficiency virus (HIV)-positive patients is caused by human papillomavirus (HPV) ${ }^{2,3}$ It is suggested that the appearance of this illness is related to the conversion of HIV into AIDS. ${ }^{2,4,5}$ Even with the introduction of highly-active antiretroviral therapy (HAART), the prevalence of HPV infection in HIV-positive patients has not decreased, nor has anal cancer incidence. ${ }^{6}$ It is well-known that HPV infection in HIV-positive patients is a risk factor for the development of squamous cell cancer of the anus. Routine screening is strongly recommended in this population in order to identify premalignant lesions. ${ }^{6}$

HPV infection frequently manifests as verrucous lesions (warts) that cause pruritus, discomfort, and, more rarely, pain or bleeding. ${ }^{2,3}$ However, some other infectious agents such as varicella-zoster virus (VZV), cytomegalovirus (CMV), molluscum contagiosum (MC), and particularly herpes simplex virus (HSV), can also cause verrucous skin lesions in HIV-positive patients. ${ }^{7}$

Herpes simplex virus is found in 29\% of MSM with symptomatic anorectal disease, ${ }^{3}$ although the majority of confirmed herpes simplex cases are reported in asymptomatic individuals. ${ }^{3,8}$ The most frequently encountered findings are ulcerated aphthous lesions, vesicles and inguinal lymphadenopathy. ${ }^{3,9}$ Additional signs and symptoms include pain, pruritus, lymphadenopathy, superficial ulcers, vesicular erosion, ${ }^{3,9,10}$ urinary retention ${ }^{11,12}$ and constipation. ${ }^{12,13}$

A very small number of cases of verrucous herpes of the perineum have been reported in the English medical literature and treatment options varied, including the use of acyclovir, ${ }^{4,14}$ valacyclovir ${ }^{15}$ and surgical resection. ${ }^{16} \mathrm{We}$

Gastroenterology Departament, Surgical Division, Hospital das Clinicas, Faculdade de Medicina da Universidade de São Paulo - São Paulo/SP, Brazil. caionahas@uol.com.br report a case of a perianal verrucous lesions that was initially suspected to be anal neoplasia, but was revealed to be a herpes infection. The patient required surgical resection after antiviral therapy failure. This article reviews the literature in order to describe the main characteristics of patients with verrucous perineal herpes infection and the outcomes of different treatment modalities.

\section{CASE REPORT}

A 39-year-old male was referred to our service who complained of having had verrucous and painful perianal nodules for 3 months. He had a 10-year history of HIV infection and had been using HAART for the last two years. His CD4 T cell count was 400/1/41 and his HIV viral load was 60.000 copies per $\mathrm{ml}$.

The proctologic exam revealed painful 2-3 $\mathrm{cm}$ verrucous perianal nodules (Figure 1). Endoscopy of the rectum and sigmoid was normal. Bilateral inguinal lymphadenopathy was detected during the physical exam. An anal pap smear revealed high-grade anal dysplasia, while a conventional pathologic exam of perianal lesions revealed no dysplasia but demonstrated cytoarchitectural alterations compatible with HSV infection. Immunohistochemical tests

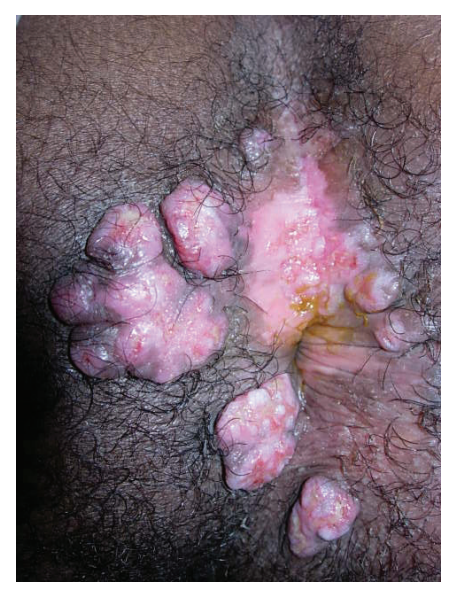

Figure 1 - Initial proctologic exam. 


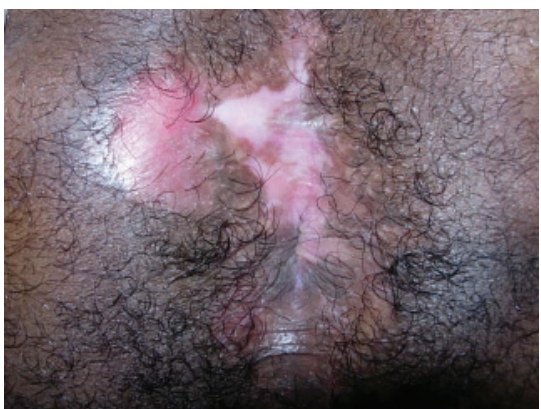

Figure 2 - Proctologic exam after surgery.

b114® for HSV type 1 and b116® for HSV type 2 from Dako Denmark A/S (Glostrup - Denmark) revealed the presence of HSV type 2. Fungal and acid-alcohol resistant bacilli screening were negative.

The patient was administered oral acyclovir for four weeks $(2.4 \mathrm{~g} / \mathrm{d})$. Because there was minimal or no regression of the lesions and persistence of the pain, we chose to resect all lesions. After surgery, the patient was administered prophylactic acyclovir. Disease recurrence was not detected after a 9-month follow-up (Figure 2).

\section{DISCUSSION}

Our review of the English language medical literature published within the last 15 years identified eight cases of verrucous perineal herpes infection. The patient characteristics are summarized and compared to the findings from our case in Table 1. Data from the literature demonstrate that this atypical presentation of herpes infection has a predilection for middle-aged males infected with HIV., 4, 15,16,17 The features of the present case were found to be similar to those reviewed in the literature.

The patient characteristics reported in the literature suggest risk factors for this uncommon presentation. An immunocompromised status, which is related to HIV infection, was reported in all cases of perianal verrucous herpetic lesions, which suggests that it may be a significant factor. Additionally, all patients had CD4 T cell counts lower than 500 cells $/ \mu \mathrm{L}$, despite the use of HAART. A history of receptive anal intercourse may also play an important role in this affliction. Although this issue was not always addressed in previous reports, two of the patients were MSM. ${ }^{4,15}$

HSV, as well as VZV, CMV, MC and HPV infections, can manifest as hyperkeratosis ${ }^{5}$ and verrucous ${ }^{4}$ lesions in HIV-positive patients. The cause for this manifestation of herpes simplex infection is unknown, ${ }^{4,14}$ although many hypotheses have been postulated. According to Smith et al., there is an increased number of dendritic cells that are positive for XIIIa factor, which might be related to the pathogenesis of $\mathrm{HIV}^{18,19}$ as these cells can work as an enervator of the virus in the skin. ${ }^{20,21}$ These dendritic cells,

Table1 - Patients with anal hypertrophic herpes.

\begin{tabular}{|c|c|c|c|c|c|c|c|c|c|}
\hline Author and Year & $\begin{array}{l}\text { Case } \\
\text { Number }\end{array}$ & $\begin{array}{l}\text { HSV } \\
\text { type }\end{array}$ & Age & Gender & $\begin{array}{l}\text { CD4+ T } \\
\text { lymphocyte } \\
\text { count } \\
(\text { cells } / \mu \mathrm{L})\end{array}$ & Treatment & $\begin{array}{l}\text { Recurrence } \\
\text { (mo) }\end{array}$ & $\begin{array}{l}\text { Follow-up } \\
(\mathrm{mo})\end{array}$ & Prophylaxy \\
\hline Tong et al. (1996) & 1 & (HSV2) & 32 & M & 13 & $\begin{array}{l}\text { Acyclovir } \\
(6 \mathrm{wks})\end{array}$ & No & NA & NR \\
\hline Saramatunga et al. (2001) & 2 & (HSV2) & 46 & M & 470 & LE alone & No & 11 & $\begin{array}{l}\text { Valacyclovir } \\
\text { (oral) }\end{array}$ \\
\hline Gubinelli et al. (2003) & 3 & (HSV1) & 46 & M & 500 & $\begin{array}{l}\text { Acyclovir } \\
\text { (oral, failure) + } \\
\text { valacyclovir } \\
\text { (oral, } 2 \text { mo) }\end{array}$ & No & 4 & $\begin{array}{l}\text { Valacyclovir } \\
\text { (oral) }\end{array}$ \\
\hline Nadal et al. (2005) & 4 & (HSV1) & 41 & M & 73 & LE alone & 12 & NA & Not used \\
\hline Nadal et al. (2005) & 5 & (HSV2) & 46 & M & 370 & LE alone & resolution & 24 & Not used \\
\hline Nadal et al. (2005) & 6 & (HSV2) & 49 & M & 186 & $\begin{array}{l}\text { Acyclovir } \\
\text { (oral, topical } \\
\text { \& IV) + LE }\end{array}$ & 10 & NA & Not used \\
\hline Nadal et al. (2005) & 7 & (HSV2) & 42 & M & 251 & $\begin{array}{l}\text { Acyclovir } \\
\text { (oral, topical } \\
\text { \& IV) + LE }\end{array}$ & 3 & NA & Not used \\
\hline Nadal et al. (2005) & 8 & (HSV2) & 54 & $\mathrm{~F}$ & 116 & $\begin{array}{l}\text { Acyclovir } \\
\text { (oral, topical } \\
\text { \& IV) + LE }\end{array}$ & resolution & 12 & Not used \\
\hline Present case & 9 & (HSV 2) & 39 & M & 400 & $\begin{array}{l}\text { Acyclovir } \\
\text { (oral) + LE }\end{array}$ & resolution & 9 & $\begin{array}{l}\text { Acyclovir } \\
\text { (oral) }\end{array}$ \\
\hline
\end{tabular}

$\mathrm{HSV}=$ herpes simplex virus; $\mathrm{NA}=$ not applicable; $\mathrm{NR}=$ not reported $\mathrm{LE}=$ local excision; $\mathrm{IV}=$ intravenous; $\mathrm{M}=\mathrm{male} ; \mathrm{F}=$ female 
can produce TNF-alpha in certain conditions, which might increase the growth index of keratinocytes ${ }^{22,23}$ and generate acanthosys and hyperkeratosis. In uninfected people, various stimuli of keratinocytes are inhibited by IFN-gamma, which is produced by cytotoxic $\mathrm{T}$ cells and $\mathrm{T}$ helper cells. This mechanism is diminished in HIV-infected patients. ${ }^{23}$

Interestingly, the majority (7/9) of the lesions in the reported cases were caused by HSV2 (cases 1, 2, and 5-9). However, due to the small number of cases, an association between HSV type and verrucous lesions cannot be assumed.

Regarding the treatment modalities and outcomes, it is difficult to compare the results from previous reports to our case. As seen in Table 1, there was significant treatment diversity among these nine cases and relatively short follow-up. However, it must be emphasized that although two cases were successfully treated with antiviral therapy alone (cases 1 and 3), the majority of cases (7/9) received local excision as part of their treatment. Local excision alone was performed in three cases (cases 1, 4 and 5) and in combination with upfront antiviral therapy in four cases (cases 6-9). Among these seven surgically treated patients, three of them presented with disease recurrence (cases 4, 6 and 7) despite the administration of oral and topical acyclovir to two of them (cases 6 and 7). The use of prophylactic acyclovir after surgical treatment effectively prevented dis- ease recurrence in our patient during the nine-month follow-up period.

According to the literature, patients with HSV infections resistant to acyclovir, which usually occurs after irregular use of the drug, ${ }^{7}$ could be treated with foscarnet ${ }^{24}$ and beta-interferon. ${ }^{10}$ Because valacyclovir is more bioavailable than acyclovir, it was more effective in the resolution of cutaneous HSV infections. ${ }^{25,26}$

Despite the relatively short follow-up period in these reports, they suggest that prophylactic use of oral acyclovir or valacyclovir may prevent recurrence. In addition, there is evidence which indicates that the survival of patients with AIDS and previous exposure to herpes virus infections may increase with chronic use of suppressive therapy with acyclovir. ${ }^{27}$ Moreover, the evidence seems to support prophylactic use of these drugs.

\section{CONCLUSION}

Atypical presentation of herpes simplex infection should be considered as a differential diagnosis of perianal neoplasia in HIV-positive patients, because the nature of this presentation may be related to an immunocompromised status. Surgical resection followed by acyclovir prophylactic treatment appears to be an effective therapy.

\section{REFERENCES}

1. Wexner SD, Smithy WB, Milsom JW, Dailey TH. The surgical management of anorectal diseases in AIDS and pre-AIDS patients. Dis Colon Rectum. 1986;29:719-23.

2. Yuhan R, Orsay C, DelPino A, Pearl R, Pulvirenti J, Kay S, et al Anorectal disease in HIV-infected patients. Dis Colon Rectum. 1998;41:1367-70

3. Quinn TC, Corey L, Chaffee RG, Schuffler MD, Brancato FP, Holmes KK. The etiology of anorectal infections in homosexual men. Am J Med. 1981;71:395-406.

4. Tong P, Mutasim DF. Herpes simplex virus infection masquerading as condyloma acuminata in a patient with HIV disease. Br J Dermatol. 1996;134:797-800.

5. Smith KJ, Skelton HG 3rd, Frissman DM, Angritt P. Verrucous lesions secondary to DNA viruses in patients infected with the human immunodeficiency virus in association with increased factor XIIIapositive dermal dendritic cells. The Military Medical Consortium of Applied Retroviral Research Washington, D.C. J Am Acad Dermatol. 1992;27:943-50. Erratum in: J Am Acad Dermatol. 1993;28:411.

6. Heard I, Palefsky JM, Kazatchkine MD. The impact of HIV antiviral therapy on human papillomavirus (HPV) infections and HPV-related diseases. Antivir Ther. 2004:9:13-22.
7. Beasley KL, Cooley GE, Kao GF, Lowitt MH, Burnett JW, Aurelian L. Herpes simplex vegetans: atypical genital herpes infection in a patient with common variable immunodeficiency. J Am Acad Dermatol. 1997:37:860-3.

8. Goldmeier D. Proctitis and herpes simplex virus in homosexual men Br J Vener Dis. 1980;56:111-4.

9. Jacobs E. Anal infections caused by herpes simplex virus. Dis Colon Rectum. 1976:19:151-7.

10. Waugh MA. Anorectal Herpesvirus hominis infection in men. J Am Vener Dis Assoc. 1976;3:68-70.

11. Goldmeier D. Herpetic proctitis and sacral radiculomyelopathy in homosexual men. Br Med J. 1979;1;2:549.

12. Samarasinghe PL, Oates JK, MacLennan IP. Herpetic proctitis and sacral radiomyelopathy - a hazard for homosexual men. Br Med J. $1979 ; 11 ; 2: 365-6$.

13. Goldmeier D, Bateman JR, Rodin P. Urinary retention and intestinal obstruction associated with ano-rectal Herpes simplex virus infection. Br Med J. 1975;24;2:425. 
14. Carrasco DA, Trizna Z, Colome-Grimmer M, Tyring SK. Verrucous herpes of the scrotum in a human immunodeficiency virus-positive man: case report and review of the literature. J Eur Acad Dermatol Venereol. 2002;16:511-5.

15. Gubinelli E, Cocuroccia B, Lazzarotto T, Girolomoni G. Nodular perianal herpes simplex with prominent plasma cell infiltration. Sex Transm Dis. 2003;30:157-9.

16. Nadal SR, Calore EE, Manzione CR, Horta SC, Ferreira AF, Almeida LV. Hypertrophic herpes simplex simulating anal neoplasia in AIDS patients: report of five cases. Dis Colon Rectum. 2005;48:2289-93.

17. Samaratunga H, Weedon D, Musgrave N, McCallum N. Atypical presentation of herpes simplex (chronic hypertrophic herpes) in a patient with HIV infection. Pathology. 2001;33:532-5.

18. Gendelman HE, Orenstein JM, Baca LM, Weiser B, Burger H, Kalter DC, et al. The macrophage in the persistence and pathogenesis of HIV infection. AIDS. 1989;3:475-95.

19. Mellert W, Kleinschmidt A, Schmidt J, Festl H, Emler S, Roth WK, et al. Infection of human fibroblasts and osteoblast-like cells with HIV-1. AIDS. 1990;4:527-35.

20. Horner PJ, Harris JR. A herpes simplex skin ulcer in a patient with AIDS—an unusual presentation. Int J STD AIDS. 1990;1:288-9.
21. Mahoney SE, Duvic M, Nickoloff BJ, Minshall M, Smith LC, Griffiths CE, et al. Human immunodeficiency virus (HIV) transcripts identified in HIV-related psoriasis and Kaposi's sarcoma lesions. J Clin Invest. $1991 ; 88: 174-85$.

22. Saiag P, Coulomb B, Lebreton C, Bell E, Dubertret L. Psoriatic fibroblasts induce hyperproliferation of normal keratinocytes in a skin equivalent model in vitro. Science. 1985;230:669-72.

23. Nickoloff BJ, Karabin GD, Barker JN, Griffiths CE, Sarma V, Mitra RS et al. Cellular localization of interleukin- 8 and its inducer, tumor necrosis factor-alpha in psoriasis. Am J Pathol. 1991;138:129-40.

24. Wagstaff AJ, Bryson HM. Foscarnet. A reappraisal of its antiviral activity, pharmacokinetic properties and therapeutic use in immunocompromised patients with viral infections. Drugs. 1994;48:199-226.

25. Baker DA. Valacyclovir in the treatment of genital herpes and herpes zoster. Expert Opin Pharmacother. 2002;3:51-8.

26. Bras AP, Sitar DS, Aoki FY. Comparative bioavailability of acyclovir from oral valacyclovir and acyclovir in patients treated for recurrent genital herpes simplex virus infection. Can J Clin Pharmacol. 2001;8:207-11.

27. Stein DS, Graham NM, Park LP, Hoover DR, Phair JP, Detels R, et al. The effect of the interaction of acyclovir with zidovudine on progression to AIDS and survival. Analysis of data in the Multicenter AIDS Cohort Study. Ann Intern Med. 1994;121:100-8. 